НАУКОВИЙ ВІСНИК

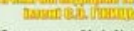

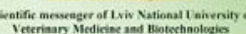

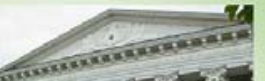

离

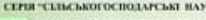
Toм 21 № 90

2019
Науковий вісник Дьвівського національного університету ветеринарної медицини та біотехнологій імені С.3. Гжицького. Серія: Сільськогосподарські науки

Scientific Messenger of Lviv National University of Veterinary Medicine and Biotechnologies.

Series: Agricultural sciences

UDC 636.2.083.312.3

\title{
Ethological observations of reproductive qualities of Aberdeen-Angus and Grey Ukrainian breed in the conditions of forest-steppe and steppe zones of Ukraine
}

\author{
V.D. Humennyi $^{1}$, S.H. Shalovylo ${ }^{2}$, B.V. Gutyj ${ }^{2}$, A.O. Boiko ${ }^{2}$ \\ ${ }^{1}$ Institute of Agriculture of Steppe zone of NAAS Ukraine, Dnipro, Ukraine \\ ${ }^{2}$ Stepan Gzhytskyi National University of Veterinary Medicine and Biotechnologies Lviv, Ukraine
}

Article info

Received 14.02.2019

Received in revised form 18.03.2019

Accepted 19.03.2019

Institute of Agriculture of Steppe zone of NAAS Ukraine, Volodymyra Vernadskoho Str., 14 Dnipro, Ukraine.

Stepan Gzhytskyi National University of Veterinary Medicine and Biotechnologies Lviv, Pekarska Str., 50, Lviv, 79010, Ukraine.

Tel.: +38-097-383-45-17 E-mail:s.shalovulo@gmail.com
Humennyi, V.D., Shalovylo, S.H., Gutyj, B.V., \& Boiko, A.O. (2019). Ethological observations of reproductive qualities of Aberdeen-Angus and Grey Ukrainian breed in the conditions of foreststeppe and steppe zones of Ukraine. Scientific Messenger of Lviv National University of Veterinary Medicine and Biotechnologies. Series: Agricultural sciences, 21(90), 98-103. doi: 10.32718/nvlveta9017

The results of researches in modern herds of meat breeds - classical British, Aberdeen-Angus and autochthonous gray Ukrainian for conducting of pollination in research farms "Polivanivka" of the Institute of Agriculture of Steppe Regions of NAAS of Ukraine and "Progress" of Chernihiv Institute of Agro-Industrial Production in 2009-2012. The ethological behavior of mothers (cows) and their calves was studied in the conditions of keeping and growing livestock on the technology of meat cattle breeding. Animals for conducting research were selected taking into account age, body weight of cows, sex calves, body weight of calves at birth. Collection of accounting materials was carried out according to the data of the primary technological and pedigree records, artificial insemination magazines, materials of ethological observations. Observations were conducted in accordance with the task of preserving genetic diversity in gene pool herds of Aberdeen-Angus and Gray Ukrainian breeds. The herds of animals in the experimental farms kept the meat keeping technology adopted by the farms. The feeding of breeding stock of animals of these breeds was carried out in accordance with established and accepted at experimental farms rations, which consisted of the presence and number of harvested at farms feed. Obtained materials indicate the plasticity and the ability to control the system reproduction reproductive population in modern economic conditions farms. Attention is paid not only to purely selective approaches, but also an attempt is made to substantiate the necessity of adapting breeding breeds to modern systems of economic relations. Knowledge of the ethology of Aberdin-Angus and gray Ukrainian breeds in the conditions of the forest-steppe and steppe zones of Ukraine will allow controlling the processes of reproduction of mother and repair animals in livestock breeding herds, as well as the conservation of genetic resources of aboriginal breeds.

Key words: ethology, gene pool, population, calving, breed, cattle, biorhythms, sexual function, cow, calf, calving, suction, reproductive ability, technology.

\section{Етологічні спостереження за відтворними якостями корів абердин- ангуської та сірої української порід в умовах лісостепової та степової зон України}

\author{
В.Д. Гуменний, С.Г. Шаловило ${ }^{2}$, Б.В. Гутий ${ }^{2}$, А.О. Бойко ${ }^{2}$ \\ ${ }^{1}$ Інститут сільського господарства степової зони НААН Украӥни, м. Дніпро, Украӥна \\ ${ }^{2}$ Львівський національний університет ветеринарної медицини та біотехнологій імені С.3. Гљсицького \\ м. Львів, Украӥна
}

Наведені результати досліджень в сучасних стадах м'ясних порід - класичної британської, абердин-ангуської і автохтонної сірої украӥнської з проведення отелення в дослідних господарствах “Поливанівка” Інституту сільського господарства степових 
районів НААН Украӥни $і$ “Прогрес” Чернігівського інституту агропромислового виробництва у 2009-2012 роках. Вивчалась етологічна поведінка матерів (корів) та їх телят за умов утримання та вирошування поголів'я за технологією м'ясного скотарства. Тварин для проведення досліджень відбирали з урахуванням віку, маси тіла корів, статі телят, маси тіла телят при народженні. Збір облікових матеріалів здійснювали за даними первинного технологічного та племінного обліку, журналів штучного осіменіння, матеріалів етологічних спостережень. Спостереження проводили згідно із завданням зі збереження генетичного різноманіття у генофондних стадах абердин-ангуської та сірої української порід. Стада тварин у дослідних господарствах утримували за прийнятою у господарствах технологією ведення м'ясного скотарства. Годівлю племінного поголів'я тварин вказаних порід проводили за встановленими та прийнятими у дослідних господарствах раціонами, які складали із наявності та кількості заготовлених у господарствах кормів. Отримані матеріали вказують про пластичність та можливість управління системою з відтворення репродуктивного поголів'я в сучасних економічних умовах господарств. Приділяється увага не тільки суто селекційним підходам, а й робиться спроба обтрунтувати необхідність адаптації розведення порід до сучасних систем господарських відносин. Знання з етологї корів абердин-ангуської та сірої украӥнської порід в умовах лісостепової і степової зон Украӥни дозволять керувати процесами відтворення маточного та ремонтного поголів'я у стадах із розведення худоби м'ясного напрямку продуктивності, а також питаннями збереження генетичних ресурсів аборигенних порід.

Ключові слова: етологія, генофонд, популяція, отелення, порода, велика рогата худоба, біоритми, статева функція, корова, теля, отелення, підсос, відтворна здатність, технологія.

\section{Вступ}

Генетичні ресурси тваринництва є одними із вагомих у стратегічному плані багатств будь-якої країни (Shmal'gauzen, 1969; Ibatullin et al., 2007; Kovalchuk, 2016). Молочне та м'ясне скотарство були, є і будуть провідними галузями у тваринництві (Golub et al., 2018). Використання їх генетичного потенціалу у багатьох випадках обумовлює економіку господарств, які займаються розвитком молочного та м'ясного скотарства (Jejsner, 1986). Конкурентні можливості розвитку галузі скотарства закладаються в період одержання i вирощування телят, 3 визначенням їх життєздатності, здоров'я, маси тіла при народженні, подальшим ростом, розвитком, витратами на годівлю, утримання. Вирощування повинно бути організоване таким чином, щоб при невеликих затратах праці й оптимальних витратах кормів забезпечити нормальний ріст і розвиток молодняку та закласти основу для прояву генетичного потенціалу продуктивності тварин (Sharan \& Shalovylo, 2018).

Тварини м'ясних порід мають добру пластичність у пристосуванні до різних природно-кліматичних умов усіх зон України та господарських умов більшості господарств. Висока продуктивність тварин, відносно швидкий темп їх відтворення та скороспілість, а також можливість краще, порівняно з іншими видами сільськогосподарських тварин, використовувати грубі та пасовищні корми і давати м'яку, соковиту яловичину - сприятимуть розведенню тварин тих порід (Kharko et al., 2017; Bodnaruk et al., 2017).

Тварини популяційних стад класичної м'ясної абердин-ангуської та вітчизняної, аборигенної сірої української порід характеризуються високою життєздатністю, міцністю конституції, доброю пристосованістю до місцевих умов, тривалістю продуктивного використання, високою плодючістю, дрібноплідністю, стійкістю до стресів та інфекційних захворювань, високим вмістом жиру та білка у молоці, добрими технологічними і смаковими показниками м'яса (Altuhov \& Rychkov, 1970; Mel'nik et al., 2002). Варті уваги також і материнські якості маточного поголів’я цих порід. У зв'язку з цим нами проведено дослідження 3 вивчення поведінки корів під час отелень та догляду корів-матерів за телятами після їх народження.
Мета роботи - дослідити особливості етологічної поведінки корів абердин-ангуської і сірої української порід та одержаного від них молодняку за природних умов пасовищного утримання.

\section{Матеріал і методи досліджень}

Дослідження проводили у дослідних господарствах "Прогрес" Чернігівського інституту агропромислового виробництва та "Поливанівка" Інституту сільського господарства степових районів НААН України, на маточному поголів $і$ племінних заводів з розведення спеціалізованої класичної м'ясної абердинангуської породи, та у популяційному стаді з утриманням аборигенної сірої української породи у літній пасовищний період 2009-2012 роках. Тварин для проведення досліджень відбирали з урахуванням віку, маси тіла корів, статі телят, маси тіла телят при народженні. Збір облікових матеріалів здійснювали за даними первинного технологічного та племінного обліку, журналів штучного осіменіння, матеріалів етологічних спостережень. Спостереження проводили згідно із завданням зі збереження генетичного різноманіття у генофондних стадах абердин-ангуської та сірої української порід (Venzhik, 1982; Altuhov, 1986). Стада тварин у дослідних господарствах утримували за прийнятою у господарствах технологією ведення м'ясного скотарства.

Годівлю племінного поголів'я тварин вказаних порід проводили за встановленими та прийнятими у дослідних господарствах раціонами, які складали із наявності та кількості заготовлених у господарствах кормів. Раціони годівлі худоби відповідали нормам (Ibatullin et al., 2007). Витрати кормів на одну корову із приплодом на підсосі становили 59-63 ц кормових одиниць на рік. Основні види кормів для худоби м'ясного напрямку продуктивності - трава зеленого конвеєра і природних пасовищ, силос, солома озимих та ярих культур, сіно, сінаж, за невеликими витратами концентрованих кормів, до 20-25\% за поживністю. М'ясним коровам на добу, на 100 кг маси тіла згодовували кормів 1,5-1,6 корм.од., на одну кормову одиницю припадало 110-115 г перетравного протеїну, 10-11 г кальцію, 5-6 г фосфору і 35-40 мг каротину. У першій половині лактації на 100 кг маси тіла згодовували 1,7-1,9 корм. од., перетравного протеїну на 
1 корм. од. - 100-110 г, кальцію 9-10 г, фосфору 4,55 г і 40-45 мг каротину. Спостереження за родами корів та підсосом телят проводили за умов випасання маточного та ремонтного поголів'я з ранньої весни до пізньої осені (Plohinskij, 1969; Admin \& Zjunkina, 1974).

Молочність маточного поголів'я визначали за масою тіла телят при відлученні від корів після підсосного періоду, у 7-місячному віці. Дослідження особливостей поведінки корів і телят абердин-ангуської та сірої української порід проводили за методикою B.I. Велікжаніна (Velikzhanin et al., 1975).

Біометричне опрацювання даних здійснювали методом варіаційної статистики за М.О. Плохинським (Plohinskij, 1969).

Постановка проблеми і стан ї̈ вивчення. Такі фізіологічні процеси, як тільність, отелення, інволюція репродуктивних органів маточного поголів'я після отелення відносять до порушень біоритмів. Взаємодія біоритмів між собою із періодично змінними умовами життя лежить в основі адаптації організму тварин. Рівень неузгодженості біоритмів у здорових корів найбільш яскраво проявляється у період отелень, що відбивається на зниженні захисних функцій організму і посиленні ризику виникнення захворювань. Перехід від тільності та відсутності лактації до отелення, а потім від відсутності тільності і початку лактації є для організму корів стресовими. За матеріалами літературних джерел, у ранній післяродовий період у корів спостерігається сильний гормональний дисбаланс із гормональною депресією. Цей період, до закриття шийки матки, $є$ вирішальним у механізмі інволюції та відновлення всієї статевої системи. Через пригнічений та ослаблений імунітет у корів виникають різні післяродові ускладнення і розлади, у тому числі й захворювання молочної залози - мастити. Все це призводить до погіршення здоров'я і зменшення молочної продуктивності корів як у період захворювання, так і впродовж усієї лактації. За даними дослідників, десинхронози приводять до вірогідного зменшення тривалості життя тварин за умов порушення біологічних ритмів, які покликані бути важливим механізмом регуляції функцій організму, забезпечуючи гомеостаз, динамічну рівновагу і процеси адаптації у біологічних системах.

Поведінка корів-матерів стосовно своїх нащадків обумовлена безумовними статевими рефлексами та материнським інстинктом. У великої рогатої худоби він розвинений досконало і проявляється ще перед появою на світ потомства. Отелення у маточного поголів'я настає після завершення визначеного терміну тільності, коли організм матері вже не може забезпечити плід поживними речовинами через плаценту. Процес виведення плоду з матки має виражену фізіологічну послідовність та особливості.

Знання складних взаємовідносин, що проходять в організмі після народження, дають можливість формувати тварин певного напрямку продуктивності, 3 ефективною трансформацією поживних речовин корму, їх здоров'я, подальшим довголіттям і пристосованістю до певних технологічних умов. Молодий організм володіє високою пластичністю, тому формування його резистентності і адаптаційних властивостей найкраще проводити на ранніх стадіях онтогенезу. За невідповідності умов годівлі, догляду і утримання тварини змушені пристосовуватись до цих обставин. Це приводить до підвищення витрат енергії, порушення обміну речовин, погіршення стану здоров'я, зниження стійкості до захворювань, їх продуктивності та перевитрат кормів на виробництво продукції.

Внаслідок проведених досліджень за поведінкою молодняку накопичено значний матеріал зі встановлення харчової активності телят у онтогенезі. За матеріалами Є.I. Адміна (Admin, 1971), середня тривалість часу з початку смоктання у телят складала 66,4 хвилини. За 12-годинний період телята молочних порід споживали 4,06 кг молозива, за добу - 5,53 кг. А.Ф. Глазов із співавторами (1983) порівнювали харчову поведінку новонароджених телят відразу відлучених від матерів (1 гр.), через 6 годин (2 гр.) і через 12 годин (3 гр.). Перший раз телята приймали молозиво відповідно через 165, 124, 117 хвилин. Тривалість прийому молозива телятами дорівнювала відповідно 4, 13 та 12 хвилин. Час до виділення меконію телятами становив 215, 167 та 148 хвилини. Ці дані свідчать про істотну різницю харчової поведінку телят, яких відразу відлучили від корів, від поведінки телят, які перебували від 6 до 12 годин із матерямигодувальницями. За даними дослідників, існує суттєва різниця у результатах досліджень харчової поведінки телят після народження. Одні автори (Admin, 1971) стверджують, що тільки 10\% телят необхідна допомога персоналу в пошуках дійок під час першої годівлі, а інші - 70 \%. За матеріалами одних дослідників, час виділення меконію дорівнював 95,8 \pm 7,52 хвилини після споживання молозива, а за інформацією інших цей час у 2-3 рази триваліший. Але усі стверджують, що утримання телят в першу добу життя разом 3 матерями сприятливо позначається як на здоров'ї телят, так і матерів. У телят, яких залишали разом із коровами-матерями, швидше з'являвся харчовий рефлекс, раніше відходив первородний кал, телята поводилися спокійніше, кратність і тривалість їх смоктання вимені, регулювалось за їх малими ковтками. Молозиво добре перемішувалося зі слиною і невеликими порціями потрапляло через стравохідний жолуб, минаючи рубець та сітку, просто в сичуг. Середньодобові прирости маси тіла досягали до 1200-1300 г.

Вирощування молодняку в багатьох випадках обумовлює оптимальні прояви генетично закладених продуктивних можливостей тварин. Знання багатогранної суті процесу росту, а також його закономірностей дозволяє управляти розвитком організму в потрібному людині напрямку. По різному впливаючи на ідентичних за якістю та походженням телят, можна виростити неоднакових за продуктивністю корів. Це можливо на основі знання закономірностей індивідуального розвитку тварин і факторів, які обумовлюють ці процеси. Індивідуальний розвиток тварин проходить за умов складних взаємодій організму і зовнішнього середовища. Характерні особливості кожного вікового періоду індивідуального розвитку організму необхідно раціонально використовувати. Енергія росту з віком зменшується, а оплата корму - збільшу- 
ється. Поряд з кількісними змінами проходить функціональна диференціація окремих тканин, органів та організму в цілому. Таким чином, вирощування високопродуктивного молодняку розподіляється на окремі періоди. Технологія вирощування постійно удосконалюється, уточнюється відповідно до сучасних досягнень науки і практики.

Отже, одержання продукції (прирости маси тіла) від утримання стад м'ясних порід великої рогатої худоби можливе при забезпеченні високого рівня відтворення стада, отримання та збереження новонароджених здорових життєздатних телят та їх подальшого інтенсивного вирощування (Admin \& Vasenkova, 1968; Admin, 1971).

\section{Результати та їх обговорення}

Важливим елементом видової характеристики великої рогатої худоби є той факт, що теля з'являється на світ цілком сформованою (анатомічно, морфологічно та фізіологічно) особиною. Відомо, що у диких предків великої рогатої худоби теля народжувалось 3 добре розвинутим зоровим та слуховим сприйняттям і відразу ж після появи на світ здатним самостійно рухатись і приймати корм, смоктати та знаходити матір у стаді за допомогою нюху та слуху. Ця властивість у процесі філогенезу була важливим біологічним фактором у збереженні виду. Якщо у диких предків великої рогатої худоби теля народжувалось масою тіла від 15 до 19 кг і у корови-матері вистачало молока лише на нетривале вигодовування, то новонароджені телята сучасних заводських як молочних, так і м'ясних порід, мають масу тіла при народженні від 25 до 45 кг. Від високоудійних корів спеціалізованих молочних порід надоюють за лактацію 8000-10000 і більше кілограм молока. У процесі філогенетичного розвитку і онтогенетичного поліпшення порід великої рогатої худоби також змінювались вимоги організму тварин до умов середовища. За час еволюції було втрачено багато притаманних виду властивостей, які забезпечували виживання тварин за умов дикої природи (це і гострота органів чуття, висока рухливість та інші реакції тварин), що спостерігаються у тварин інших видів, які збереглися у дикій природі. Водночас 3'явились нові властивості тварин, найбільш позитивні 3 яких були відібрані людиною шляхом селекції. Поступово змінилась і реакція тварин на умови середовища.

Аналіз проведених нами досліджень перебігу отелень корів абердин-ангуської і сірої української порід та показників маси тіла новонароджених телят свідчать, що отелення у корів проходили без надання сторонньої допомоги обслуговуючим персоналом. Корови телились за природних умов утримання, самостійно на природних пасовищах.

Спостереження показали, що перед наближенням до отелення корови намагались відокремлюватись від загального стада і починали повіодитися дуже неспокійно, “порушуючи” звичайний “режим дня”, встановлений для стада, що перебували на випасі. Вони відставали від стада, вибирали для родів відокремлене від людей та інших тварин місце. Ретельно його огля- дають, все, що можуть обнюхують, прислухаються, потребують повного спокою, тиші. Вивчають “свою вибрану для родів територію”. За часом народження телят у сірих українських корів після відходу навколоплідної води проходить 1,5-2 години, із коливаннями від 20 до 127 хвилин. Отелення у корів, що перебували під нашими спостереженнями, проходили відносно легко. Корови сірої української породи проявляють активне материнське піклування за новонародженими телятами. Після отелення, яке у більшості випадків проходить у стані, коли корови лежать, вона відпочивають від 2 до 8 хвилин. Відпочиваючи, корови весь час намагаються підняти голову, при цьому подають звукові сигнали і стараються дивитися в бік телят, спостерігають за проявами ознак життя та поведінкою. Після короткого відпочинку корови швидко піднімаються на ноги, обнюхують телят і починають енергійно, навіть жадібно, вилизувати новонароджений плід. Ми спостерігали два етапи активності вилизування телят коровами. Перший етап проходить до часу виділення плодом меконія (первородного калу) i поїдання його коровами. Другий етап - після споживання меконію. Середня тривалість більш активного першого вилизування телят становила до 48 хвилин 3 коливаннями від 36 до 75 хвилин. Загальний час вилизування за першу добу склав 138 хвилин. Облизування теляти має важливе біологічне значення - теля швидше висихає, активізується та поліпшується кровообіг і дихання, а також терморегуляція. Шерсть набуває гарного блискучого вигляду. Відомо, що всі новонароджені класу ссавців не мають лізоциму. Лізоцим материнської слини сприятливо діє на шкіру, надає їй бактерицидних властивостей та захищає телят. За допомогою лізоциму у новонароджених телят проходить знезараження пуповини.

Процес адаптації та вставання на ноги майже у всіх новонароджених телят сірої української породи проходить доволі швидко. Ці дії залежать від статі, маси тіла плода при народженні. Першими, у межах 14-27 хвилин, на ноги піднімаються телички. Бугайці, маючи більшу масу тіла при народженні, починають вставати на 20-45 хвилині після родів. Через деякий час та кількох невдалих спроб вставання і падіння, теля намагається твердо стояти на ногах, починаючи пошук вимені і перші невдалі спроби підсису. Під час вставання на ноги у телят відкривається стравохідний жолоб і вони готові до споживання молозива.

За нашими спостереженнями, телята досліджуваних порід витрачали на пошуки дійок від 20 до 60 хвилин. Протягом 8 годин після родів у телят вказаних порід на підсис витрачалося 84,4 хвилини. Акт ссання є безумовним рефлексом, пов'язаним із діяльністю шлунково-кишкового тракту. У прояві рефлексу ссання основну роль відіграють зовнішні імпульси, подразнення у зоні губ та стінок передньої частини ротової порожнини, які надає корова теляті язиком при його облизуванні. Рефлекс ссання з'являється після народження, через декілька хвилин і зумовлюється почуттям голоду, яке виникає після припинення плацентарного живлення. Новонародженим телятам необхідно спожити молозиво через 30-40 хвилин після родів, коли відкритий стравохідний жолоб, але 
не пізніше ніж 1-1,5 години після отелення корови у кількості 1,5-2 кг. У харчуванні новонароджених телят молозиво є єдиним, найціннішим та незамінним продуктом. При споживанні молозива телята засвоюють антитіла, у т. ч. гамма-глобуліни, які є основними захисними тілами в організмі телят, набувають імунітету проти дії різних хвороботворних мікроорганізмів.

Ми спостерігали прийом молозива після народження, виявлення рефлексу ссання і частоту підсосу корів протягом першої доби. Перші спроби споживання молозива у телят сірої української породи в середньому наступали на 32 хвилині після народження телят. Коливання становило 22-58 хвилин. Телята ссуть корів повільно, перебираючи дійки. Фахівцям бажано прослідкувати, щоб теля спожило молозиво після першого вставання на ноги, коли у нього відкривається стравохідний жолуб. Якщо споживання молозива зволікається, то телята не одержать необхідних їм імунних тіл і будуть хворіти на шлунковокишкові захворювання. у. У період годівлі телят молозивом, а потім молоком у них проходить сичужне травлення, коли корм надходить безпосередньо до сичуга. Починаючи з першої годівлі, безперервно іде секреція шлункового соку. За першу добу телята до 14-17 разів підсисають корів.

При перших спробах теляти ссати корова стає до нього боком, паралельно і весь час активно вилизує задню третину тулуба, зону голодної ямки, задні кінцівки. Особлива увага надається в ділянці кореня хвоста, зовнішніх статевих органів. До отелення, під час і після отелення корови весь час подають сигнали. Звукова тональність, тембр голосу, частота сигналів у кожної корови своя. Після висмоктаних перших порцій молозива, на 3-5 хвилині під час його подальшого споживання, у телят починає відходити меконій. Молозиво діє як легке проносне на травний тракт новонародженого теляти, що допомагає швидко звільнити його від накопиченого у кишечнику первородного калу. Корови чекають цієї миті, і при виділенні меконію, густого, щільної консистенції, зеленого або жовтого, темно-коричневого, а інколи і чорного кольору первородного калу, корови активно починають його захоплювати язиком і споживають. Після поїдання меконію тварини заспокоюються. Тобто, закінчився перший, активний етап корови з догляду за новонародженим телям та його ретельне вилизування. За нашими підрахунками, корови понад три тисячі разів (3370 із коливаннями від 1780 до 3698 разів), до відходу і споживання ними меконію язиком проводили вилизування телят. Вважаємо, що споживання меконію $є$ також одночасним сигналом корів, що роди пройшли нормально і тварина може готуватись до подальшого процесу відділення посліду. Після поїдання коровами меконію їх активність щодо догляду за телятами знижувалася. Встановлено, що у корів, які не перебували із телятами після родів і не споживали меконію, відбулося затримання інволюції матки після отелення.

Третя стадія родового процесу завершується звільненням матки від хоріону (плодових оболонок) i триває у межах від 3,5 до 6 годин.
У перші дні після родів, які проходили на пасовищі, корова перебуває поряд із приплодом, доглядає за ним та оберігає його, пасеться сама та годує теля. Під час випасання чи відпочинку корови теля весь час у їі полі зору. У перші дні новонароджене теля стає рідко. Коли теля піднімається на ноги, у нього проходить діурез, а потім теля починає шукати вим'я матері i підсисає його. Після цього недовго стоїть на ногах $\mathrm{i}$ знову лягає на відпочинок. До стада корів у перші дні корова не наближається. На нашу думку, така поведінка тварини дає можливість розірвати зв'язок корови iз пасажуючою мікрофлорою у стаді та закріпити біологічний зв'язок “корова - теля”. За літературними даними (Sel'e, 1987) та нашими спостереженнями, корови приводять телят до стада корів через 5-7 днів після отелення. Корова пізнає своє теля за допомогою нюху, слуху, дотику і насамкінець - зору. Новонароджені телята пізнають свою матір за запахом та звуком. У кожної тварин свій специфічний запах. Це суміш природних запахів, які визначаються генами, типом шкіри, кольором волосяного покриву, типом нервової діяльності темпераментом і навіть раціоном харчування та набором кормів у раціоні перед отеленням та під час родів (Sel'e, 1972).

За аналізом маси тіла новонароджених телят досліджуваних порід суттєвої різниці не виявлено. Маса тіла телят абердин-ангуської породи становила 2527 кг. Ліміти живої маси становили від 24,8 кг до 28,7 кг. Мінливість ознаки за живою масою - 13,1\%. Маса тіла новонароджених бугайців була 26-27 кг, а теличок 25-26 кг. Молочність корів невисока - 11001250 кг за лактацію. За оптимальних умов годівлі телята абердин-ангуської породи у 8-місячному віці досягли маси тіла 185-220 кг. Відтворювальна здатність маточного поголів'я стада становила 91\%. У маточного поголів'я спостерігалась добре виражена сезонність отелень (січень - квітень).

За умов тривалого чистопородного розведення у невеликому закритому стаді тварини сірої української породи зберігають основні специфічні породні особливості: добру пристосованість до місцевих умов, дрібноплідність і високу репродуктивну здатність. Жива маса телят при народженні по стаду складає 5$6 \%$ від живої маси маточного поголів'я - 26,8 кг (26 + 35 кг) за мінливістю ознаки 14,5\%. При цьому маса тіла бугайців становить 30-35 кг, а теличок 26-31 кг. Коефіцієнт дрібноплідності у маточного поголів'я становить 0,052-0,061 і на такому рівні залишається понад 45 останніх років.

Отже, вирощування одержаного молодняку і формування майбутньої м'ясної продуктивності телят $є$ найвідповідальнішим і найважливішим процесом у молочний період в м'ясному скотарстві. Інтенсивність росту отриманих телят, направлене їх вирощування повинно бути організоване таким чином, щоб за невеликих затрат праці, оптимальних витрат кормів забезпечити інтенсивний ріст і розвиток молодняку та закласти основу для виявлення генетично закладеної високої продуктивності. 


\section{Висновки}

Знання з етології корів абердин-ангуської та сірої української порід в умовах лісостепової і степової зон України дозволять керувати процесами відтворення маточного та ремонтного поголів'я у стадах із розведення худоби м'ясного напрямку продуктивності, а також питаннями збереження генетичних ресурсів аборигенних порід.

\section{References}

Admin, E., \& Vasenkova, N. (1968). Otdyh korov pri bezprivjaznom soderzhanii. Molochnoe i mjasnoe skotovodstvo, 10, 41 (in Russian).

Admin, E.I. (1971). Izuchenie s.-h. zhivotnyh v bol'shih gruppah. Nauchno-tehn. bjul. NII zhivotnovodstva Lesostepi i Poles'ja USSR, 2, 44-50 (in Russian).

Admin, E.I., \& Zjunkina, E.N. (1974). Povedenie korov pri raznyh tehnologicheskih soderzhanijah. Zhivotnovodstvo, 4, 64-65 (in Russian).

Altuhov, Ju.P. (1986). Geneticheskie processy v populjacijah. Moskva: Nauka (in Russian).

Altuhov, Ju.P., \& Rychkov, Ju.G. (1970). Populjacionnye sistemy $\mathrm{i}$ ih strukturnye jelementy. Geneticheskaja stabil'nost' i izmenchivost'. Zhurn. obshh. biologii, 31(5), 507-526 (in Russian).

Bodnaruk, V.Y., Muzyka, L.I., Bodnar, P.V., Zhmur, A.J., \& Orihivsjkyj, T.V. (2017). New possibilities of effective breeding in cattle based on the study of the genome. Scientific Messenger LNUVMB, 19(79), 3237. doi: $10.15421 /$ nvlvet7907.

Golub, O.M., Shalovylo, S.G., Bojko, A.O., \& Oseredchuk, R.S. (2018). Extraterritorialconstitutional features of Black-and-Spotted Dairy cows of different affinity and production types. Scientific Messenger of Lviv National University of Veterinary Medicine and Biotechnologies, 20(89), 41-46. doi: 10.32718/nvlvet8907.

Ibatullin, I.I., Melnychuk, D.O., \& Bohdanov, H.O. (2007). Hodivlia silskohospodarskykh tvaryn. Vinnytsia: Nova Knyha (in Ukrainian).
Jejsner, F.F. (1986). Ispol'zovanie i sovershenstvovanie serogo ukrainskogo skota. Katalog zhivotnyh seroj ukrainskoj porodi krupnogo rogatogo skota. K.: Urozhaj (in Russian).

Kharko, M.V., Denkovich, B.S., Pivtorak, Y.I., Naumyuk, A.S., Petryshak, R.A., \& Holodyuk, Y.P. (2017). Milk yield and metabolic processes in cows during the usage of the biosprint drug in the diet structure. Scientific Messenger LNUVMB, 19(79), 122-126. doi: $10.15421 /$ nvlvet7924.

Kovalchuk, N.A. (2016). Ekolohichni problemy tvarynnytstva. Naukovyi visnyk LNU veterynarnoi medytsyny ta biotekhnolohii. Seriia: Silskohospodarski nauky, 18(1), 199-203. https:/nvlvet.com.ua/index.php/agriculture/article/vie w/3528.

Mel'nik, Ju.F., Burkat, V.P., \& Guzev, I.V. (2002). Selekcionnyj process i sostojanie geneticheskih resursov zhivotnovodstva $\mathrm{v}$ Ukraine. K.: Agrarnaja nauka (in Russian)

Plohinskij, N.A. (1969). Rukovodstvo po biometrii dlja zootehnikov. Moskva: Kolos (in Russian).

Sel'e, G. (1972). Ot mechty k otkrytiju. Per. s angl. Progress. Moskva (in Russian).

Sel'e, G. (1987). Na urovne celogo organizma. Nauka. Moskva (in Russian).

Sharan, M., \& Shalovylo, S. (2018). Subsidiary methods of pregnancy diagnosis in diary cattle - alternative for the future. Scientific Messenger of Lviv National University of Veterinary Medicine and Biotechnologies, 20(89), 108-113. doi: 10.32718/nvlvet8920

Shmal'gauzen, I.I. (1969). Faktory jevoljucii. Teorija stabilizirujushhego otbora. Moskva: Nauka (in Russian).

Velikzhanin, V.I., Vasil'eva, E.N., Kulikov, V.B., \& Soldatov, A.S. (1975). K probleme povedenija sel'skohozjajstvennyh zhivotnyh. Vopr. Zoopsihologii, jetologii i sravnit. psihologii. M., 108-109 (in Russian).

Venzhik, S. (1982). Sohranenie geneticheskih fondov. Aktual'nye voprosy prikladnoj genetiki $\mathrm{V}$ zhivotnovodstve. M.: Kolos, 59-70 (in Russian). 